\title{
Frekwencja wyborcza a stan polskiej demokracji
}

$\mathrm{W}$ TOKRESIE PRZEDWYBORCZYM, a szczególnie w ostatnich dniach kampanii wyborczej także w Polsce, głównie za pośrednictwem środków masowego przekazu, kwestią istotną, zyskującą znaczny rozgłos medialny staje się oczekiwana (prognozowana) frekwencja wyborcza. Apel organizacji, znanych osób oraz samych polityków może oznaczać, że pożądana jest wysoka partycypacja wyborcza obywateli. Z punktu widzenia systemu demokratycznego, który zakłada wybór reprezentantów narodu w powszechnych wyborach oraz rządy większości, jest to o tyle ważne, że wysoka frekwencja wyborcza pozwala legitymizować system polityczny ${ }^{1}$. Per analogiam: stopień legitymizacji systemu przez społeczeństwo rośnie wraz ze zwiększającym się poziomem frekwencji wyborczej. Jeżeli powyższe twierdzenie jest prawdziwe to można zakładać, uwzględniając historię wyborów w Polsce po 1989 roku, że funkcjonowanie polskiej demokracji jest - delikatnie mówić oceniane przez obywateli niejednoznacznie. Czy oznacza jednak brak akceptacji?

\section{UCZESTNICTWO WYBORCZE A DEMOKRACJA}

WSPÓŁCZESNA DEMOKRACJA NIE MOŻE ISTNIEć BEZ WYBORÓW. Zauważył to już Robert Dahl, podkreślając że wybory są jednym z kluczowych wymagań proceduralnych demokracji ${ }^{2}$. Do takich samych wniosków można dojść, odwołując się do greckiego źródła terminu. Demokracja, to władza ludu, co oznacza, że zakłada się „istnienie aktywnego bytu

${ }^{1}$ Pojęcie wysokiej frekwencji zostało tu użyte w znaczeniu takiej frekwencji, która jest pożądana przez system, czyli wysokiej do takiego stopnia, że nie naraża systemu politycznego na niewłaściwe funkcjonowanie. System demokratyczny nie jest zainteresowany maksymalną frekwencją, gdyż taka sytuacja może powodować dezorganizację, czego przykładem były wybory w 2007 r., podczas których liczba osób głosujących przewyższyła liczbę wydrukowanych i przygotowanych kart do głosowania. Ponadto, świat całkowicie zdemokratyzowany byłby niemożliwy do rządzenia ze względu na niską efektywności procesu decyzyjnego.

${ }^{2}$ Robert Dahl stwierdzil, że „demokracja w jej klasycznym rozumieniu oznaczała przede wszystkim bezpośredni udział obywateli; demokracja albo jest partycypacyjna, albo jej w ogóle nie ma”. Por.: R. Dahl, Demokracja i jej krytycy, Kraków 1995, s. 316. 
(demos), który uczestniczy (właśnie-uczestniczy!) we władzy (kratos, kratia)"3.

Do podobnych konkluzji doszedł także Janusz Reykowski. Wskazał on właśnie na wolne wybory jako warunek sine qua non systemu demokratycznego. Dowodów na poparcie tej tezy jest zresztą więcej. W 1995 roku, 85\% respondentów podało, że wolne wybory legitymizują demokrację ${ }^{4}$. Nie ulega wątpliwości, że wymagania są obustronne: obywatele oczekują wolnych wyborów, zaś demokracja opiera się na uczestnictwie obywateli w takich wyborach.

W 2010 r., badacze pominęli „minimalistyczne” ujęcie demokracji jako procedury wyborczej i przedstawili badanym 23 wskaźniki demokracji, z których najważniejszymi okazały się: równość wobec prawa, równe możliwości kształcenia, dobór najlepszych polityków do rządzenia krajem, a także ochrona wolności osobistej obywateli. Dosyć ogólnie sformułowany marker: „aktywność obywateli w życiu publicznym”, został uznany przez nie mniej niż 60\% respondentów za ważną zasadę demokracji5.

Nieco inne ujęcie zaproponował Giovanni Sartori, podkreślając, że „uczestnictwo, właściwie i sensownie rozumiane, polega na osobistym udziale, aktywnym i chętnym włączaniu się. Uczestnictwo nie jest więc prozaicznym byciem częścią czegoś (zwykle byciem wplątanym w jakieś zdarzenia), a tym bardziej nie chcianym, przymusowym włączeniem do czegoś. Uczestnictwo to ruch samoistny, dokładne przeciwieństwo bycia włączonym w ruch (z cudzej woli), czyli przeciwieństwo zmobilizowania"6. G. Sartori, reprezentując stanowisko partycypacjonistów, podkreślał, że warunkiem istnienia ładu demokratycznego jest pełne, samoistne i prawdziwe uczestnictwo w systemie ${ }^{7}$. Nie ograniczał się więc jedynie do uczestnictwa wyborczego, a zwracał uwagę na zaangażowanie obywatelskie w wiele typów aktywności politycznej.

${ }^{3}$ M. Cześnik, Partycypacja wyborcza $w$ Polsce. Analiza porównawcza, Warszawa 2007, s. 14 .

${ }^{4}$ Por. J. Reykowski, Subiektywne znaczenia pojęcia „demokracja” a ujmowanie rzeczywistości politycznej, [w:] Potoczne wyobrażenia o demokracji. Psychologiczne uwarunkowania i konsekwencje, red. J. Reykowski, Warszawa 1995, s. 19-53.

${ }^{5}$ Zob. M. Feliksiak, Postawy wobec demokracji, jej rozumienie i oceny. Komunikat z badań, CBOS, Warszawa 2010. Ogólna nazwa wskaźnika mogła wpłynąć na zaniżony wynik. Badania z 2010 r. nie dostarczają wyników dot. stricte wyborów. Na aktywność obywatelską bowiem poza wyborami mogą składać się takie elementy jak: uczestnictwo w stowarzyszeniach lub innych organizacjach, sprawowanie władzy, poparcie dla działań władz lub protest itd.

${ }^{6}$ G. Sartori, Teoria demokracji, Warszawa 1998, s. 148.

7 Ibidem. 
Przymiotnik „prawdziwy” miał potęgować sens szerszego uczestnictwa, stając się jego substancją.

Opozycyjną do ujęcia G. Sartoriego koncepcją była proceduralna teoria demokracji Josepha A. Schumpetera. O ile w przypadku pierwszej nacisk położono na udział obywatelski, o tyle w koncepcji J. A. Schumpetera można było mówić o udziale elit (elitarystyczna teoria demokracji), które konkurują o głosy wyborców. Rolą tych ostatnich jest jedynie głosowanie. Inne formy aktywności obywatelskiej zostały pominięte, zaś cel demokracji sprowadzony został do decyzji wyborców ${ }^{8}$.

Niezależnie od powyższego jedną z istotnych funkcji uczestnictwa wyborczego jest legitymizacja systemu, która jest kluczową cechą demokracji. Seymour M. Lipset stwierdzil, że „brak partycypacji i reprezentacji odzwierciedla również nieistnienie społeczeństwa obywatelskiego i w konsekwencji brak lojalności wobec całego systemu”". Tym samym niska frekwencja wyborcza może świadczyć o delegitymizacji systemu. Potwierdzają to tezy Davida Beethama, który mówił o wielowymiarowym charakterze legitymizacji, wskazując na jej trzy poziomy: reguł, przekonań i zachowań. Trzeci ze wskazanych wymiarów legitymizacji zakładał czynne i dobrowolne przyzwolenie podporządkowanego na zależność od władzy, które przejawia się między innymi w udziale w wyborach (mobilizacyjny tryb poparcia). Z drugiej strony, można polemizować z tezami D. Beethama, gdyż niska frekwencja niekoniecznie musi świadczyć o delegitymizacji systemu. Na problem ten zwracał uwagę, cytowany przez S. M. Lipseta, David Riesman, twierdząc że „bierność może odzwierciedlać fakt, iż ludzie mają bardziej interesujące zajęcia niż zajmowanie się polityką, a ciała rządowe i rozbudowane organizacje funkcjonują dobrze pomimo takiej apatii”"

Ludzie nie chodzą na wybory z różnych powodów: są zadowoleni z istniejącej sytuacji, wykonują inne, ważniejsze i zajmujące czynności albo twierdzą, że polityka funkcjonuje prawidłowo, więc nie ma sensu rezygnować z absorbujących zajęć. Myśl D. Riesmana uwzględniła drugą stronę legitymizacji, którą można nazwać „legitymizacją bierną". Otóż poprzez świadome niepójście do urn, wyborcy przyzwalają

${ }^{8}$ J. Schumpeter, Kapitalizm, socjalizm, demokracja, Warszawa 1995, za: M. Cześnik, Partycypacja..., op. cit., s. 16.

${ }^{9}$ S. Lipset, Homo politicus. Spoteczne podstawy polityki, Warszawa 1998, s. 231.

${ }^{10}$ H. Finer, G. Hicks, D. Riesman, Political Apathy in America, „The University of Chicago Round Table”, nr 657, 29 października 1950, za: S. Lipset, Homo..., op. cit., s. 232. 
(jako podporządkowani), na bycie rządzonym, czego wyrazem jest akceptacja systemu w ogóle. Co więcej, teza Francisa Wilsona zdaje się posiadać podobny wydźwięk, jako że F. Wilson twierdzi, iż „w społeczeństwie, w którym jedynie 50\% elektoratu bierze udział w wyborach, oczywiste jest, że polityka w jakiś sposób zadowala jednostki en masse w państwie. W miarę wzrostu odsetka głosujących powyżej, powiedzmy, 90\%, staje się widoczne, że napięcia walki politycznej rozciągają do granic wytrzymałości wolę utrzymania rządów konstytucyjnych" ${ }^{11}$.

A jak kwestia uczestnictwa wyborczego, a więc i legitymizacji władzy wygląda w Polsce? Jakie przełożenie na prawomocność władzy ma frekwencja wyborcza?

\section{Frekwencja wyborcza w Polsce Po 1989 ROKU}

KAZIMIERZ KIK ZAUWAŻYŁ, że jednym z wyznaczników życia politycznego w Polsce w latach 1990-2005 było zjawisko stopniowo narastającej absencji wyborczej ${ }^{12}$. W przypadku wyborów prezydenckich taka sytuacja rzeczywiście miała miejsce (por. rys. 1). Jednak wyniki frekwencji wyborów samorządowych oraz parlamentarnych z tego okresu pozwalają twierdzić, że w ciągu 15 lat w Polsce występowała zmienna tendencja: w jednym roku wyborczym odnotowywano wzrost, zaś w następnym spadek frekwencji wyborczej. Co więcej, na uwagę zasługuje fakt, że od wyborów parlamentarnych z 1989 r., kiedy frekwencja wyniosła $62,7 \%$ oraz wyborów prezydenckich z 1990 r. z frekwencją wynoszącą $66,63 \%$, do czasów obecnych nie odnotowano wyższych wyników frekwencji wyborczej. Dwa ostatnie wyniki frekwencji wyborczej, z każdego typu głosowania powszechnego w Polsce, pozwalają twierdzić, że wartość frekwencji wyborczej jest bliska 50\%. Od 2005 roku frekwencja dwa razy przekroczyła poziom 50\%: w trakcie wyborów parlamentarnych w $2007 \mathrm{r}$. wyniosła 53,88\%, w wyborach prezydenckich w 2010 r. $-54,94 \%$.

Szczegółowe porównanie wszystkich rodzajów głosowań powszechnych w Polsce pozwala na wyciągnięcie kilku wniosków.

${ }^{11}$ F. G. Wilson, The Inactive Electorate and Social Revolution, „Southwestern Social Science Quarterly” nr 16, 1936, za: S. Lipset, Homo..., op. cit., s. 232. Potwierdzeniem tez F. Wilsona było podsumowanie badań statystyk wyborczych na całym świecie, dokonane przez Herberta Tingstena, z którego wynikało, że Niemcy i Austria zanotowały wysoką frekwencję w czasie rozpadu demokracji, co było objawem spadku konsensusu. Zob. H. Tingsten, Political Behavior, za: S. Lipset, Homo..., op. cit., s. 232,

${ }^{12} \mathrm{~K}$. Kik, Absencja wyborcza w III RP - główne uwarunkowania, [w:] Zachowania wyborcze społeczeństwa polskiego po 1989. Próba oglądu i analiza zjawiska, red. A. Kasińska-Metryka, Kielce 2006, s. 25. 
Po pierwsze, najwyższą frekwencję wyborczą obserwowano w wyborach prezydenckich. Tylko w 2005 r. w tego typu wyborach wzięło udział mniej niż 50\% uprawnionych (49,74\%). W pozostałych latach wyborczych stopień uczestnictwa wyborczego był wysoki, gdyż wynosił powyżej 60\% oraz niespełna 55\% w wyborach w 2010 r. Po drugie, w sytuacji wyborów parlamentarnych można mówić o względnie wysokiej frekwencji: w większości sytuacji wynosiła ona powyżej lub prawie 50\%. Tylko w dwóch okresach nastąpiło „załamanie”, wówczas zagłosowało ok. 40\% uprawnionych (1997 r. i 2005 r.).

Rysunek 1. Frekwencja wyborcza w głosowaniach powszechnych w Polsce po 1989 r.

\section{Wybory prezydenckie}

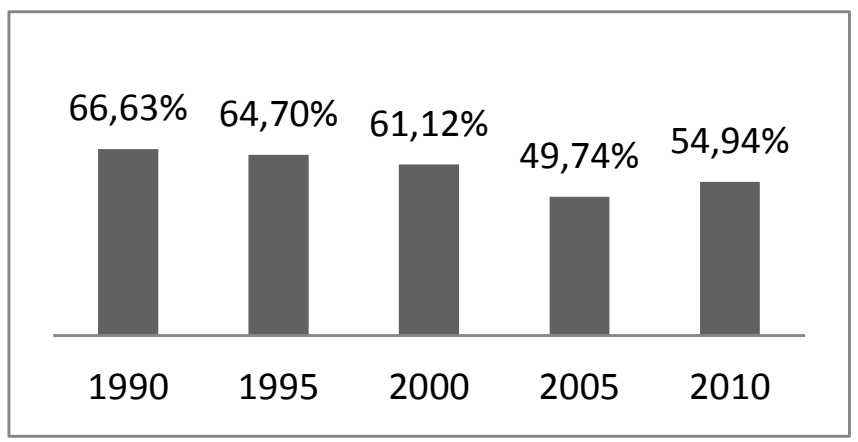

Wybory parlamentarne

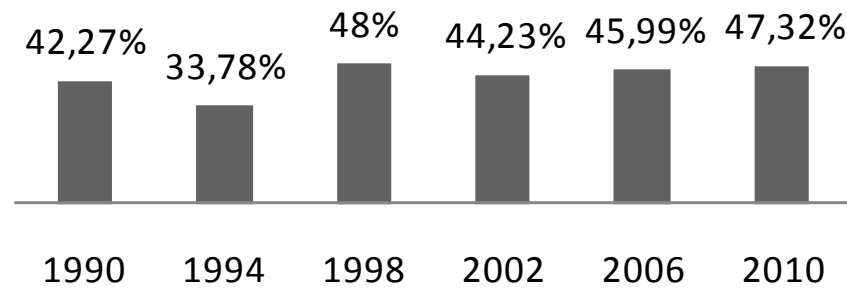




\section{Wybory samorządowe}

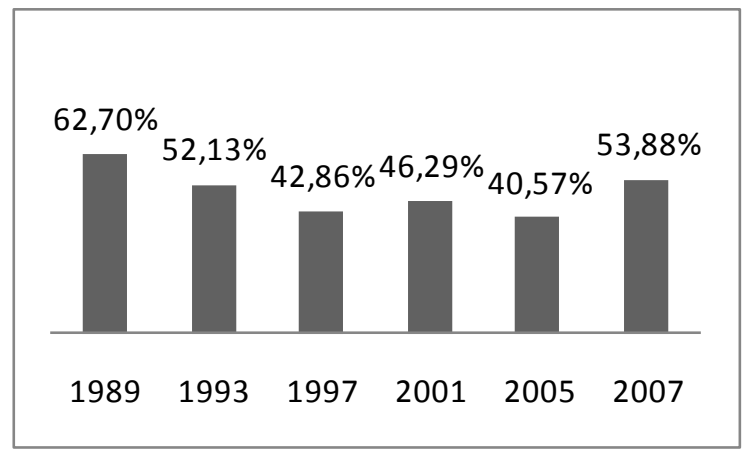

Źródło: Opracowanie własne na podstawie: T. Sasińska-Klas, O absencji wyborczej $w$ Polsce, [w:] Wybory samorzqdowe w kontekście mediów i polityki, red. M. Magoska, Kraków 2008, s. 41 oraz PKW, Wybory samorzq̨dowe i referenda lokalne, http://www.pkw.gov.pl/pkw2/index.jsp?place=Menuo1\&news_cat_id= 24\&layout $=1$, 03.07.2011 r.

Charakterystyczne dla frekwencji w Polsce jest również zjawisko niższego uczestnictwa uprawnionych w wyborach samorządowych $\mathrm{w}$ porównaniu $\mathrm{z}$ wyborami parlamentarnymi oraz prezydenckimi. Tam frekwencja nigdy nie wyniosła 50\%. Najwyższą wartość odnotowano w 1998 r., kiedy zagłosowało 48\% uprawnionych. Jest to o tyle zadziwiające, że „uczestnictwo takie [w wyborach lokalnych] można uznać za leżące wręcz w ekonomicznym interesie poszczególnych osób” ${ }^{13}$. Lokalne wybory są istotne z punktu widzenia bliskości przestrzennej i społecznej spraw i osób, których dotyczą. Co więcej, skutki podejmowanych decyzji ilościowych i jakościowych ${ }^{14}$ są istotne ze względu na wspomnianą bliskość, dlatego wyborcom powinno bardziej zależeć na tego typu wyborach. Zadania szczebla lokalnego w porównaniu do centralnych są bardziej konkretne i szczegółowe. Również problemy są bardziej techniczne i, w inny sposób, niż ogólnokrajowe, interesujące i poruszające mieszkańców. Podlegają też

${ }^{13}$ A. Janus, Polityczna partycypacja lokalna wyborcza i referendalna, [w:] Samorząd lokalny $w$ Polsce, red. S. Michałowski, A. Pawłowska, Lublin 2004, s. 176.

${ }^{14}$ Przez decyzje ilościowe rozumiem liczbę osób podejmujących decyzję o głosowaniu. Natomiast decyzje jakościowe, to konkretny wybór, rozumiany w sposób aksjologiczny: dobry albo zły. Każda z tych decyzji w sytuacji społeczności lokalnej jest bardziej odczuwalna, aniżeli w przypadku wyborów ogólnokrajowych choćby z racji wspomnianych bliskości przestrzennych oraz osobowych. 
większej kontroli ludności ${ }^{15}$. Wyborcy, którzy nie biorą udziału w głosowaniu niejako odsuwają się od kontroli lokalnych władz, wiążącej się z ich rozliczaniem. Niska frekwencja w wyborach samorządowych wskazuje na problem w funkcjonowaniu społeczności lokalnych: ludność ta bowiem bardziej interesuje się wyborami ogólnokrajowymi, niż lokalnymi, mimo, że to wybory samorządowe mają wpływ na sprawy, które bezpośrednio dotyczą lokalnej społeczności. Problem może wynikać ze świadomości oraz z wpływu czynników tj. np. medialne nagłaśnianie kampanii do wyborów szczebla ogólnokrajowego. Medialny szum wokół takich wyborów sytuuje lokalne głosowanie na dalszym planie, w cieniu pozostałych typów głosowania. Ponadto wyborcy mają większą możliwość zapoznania się z programami oraz sylwetkami polityków krajowych ze względu na ich częste występowanie w wielu środkach masowego przekazu. Gorzej wygląda sytuacja w przypadku lokalnych polityków, o których wyborca musi sam się dowiadywać, na co zazwyczaj brakuje czasu, sił fizycznych i psychologicznych ${ }^{16}$. Z badań CBOS wynika, że w 2010 r. 66\% wyborców nie wiedziało, kto będzie kandydował w wyborach na stanowisko wójta, burmistrza i/lub prezydenta miasta ${ }^{17}$.

Specyficzne dla polskiej rzeczywistości jest również to, że wartości przypisywanej wyborom samorządowym nie odzwierciedla frekwencja wyborcza. Z badań Centrum Badania Opinii Społecznej przeprowadzonych na kilka miesięcy przed wyborami samorządowymi w 2010 roku, wynikało że elekcje samorządowe są postrzegane jako najbardziej znaczące spośród czterech rodzajów powszechnych głosowań.

${ }^{15}$ Więcej o specyfice samorządu terytorialnego zob.: P. Sarnecki, Ordynacja wyborcza $w$ wyborach samorzadowych, [w:] Wybory samorzadowe w kontekście mediów i polityki, red. M. Magoska, Kraków 2008, s. 12.

${ }^{16} \mathrm{Z}$. Krasnodębski twierdzi np., że dużą rolę odgrywają media. „W przypadku wyborów parlamentarnych i prezydenckich mamy do czynienia z większym stężeniem emocji rozbudzanych przez media, więcej się o nich mówi w telewizji. Natomiast w wyborach samorządowych ludzie muszą bardziej samodzielnie i świadomie podejść do sprawy, sami się zorientować w sytuacji i podjąć decyzję, a to wymaga dojrzałości obywatelskiej”. Zob. P. Jarosińska, Podziały schodzą na poziom lokalny, „Nasz Dziennik”, http://www. naszdziennik.pl/index.php ?dat=20101123\&typ=po\&id=po13.txt, 22.06.2011 r.

${ }^{17}$ „Jak się okazuje, na ponad dwa miesiące przed głosowaniem wiedza Polaków o kandydatach na najwyższe urzędy w ich miejscowościach była niewielka. Tylko co trzeci badany (34\%) przyznał, że słyszał o przynajmniej jednym kandydacie, w tym niespełna co piąty (19\%) - o kilku osobach zamierzających ubiegać się o urząd wójta, burmistrza lub prezydenta miasta”. Zob. R. Boguszewski, Wybory samorzadowe - znaczenie, zainteresowanie oraz deklaracje udziału $w$ głosowaniu. Komunikat z badań, CBOS, Warszawa 2010, http://www.cbos.pl/SPISKOM.POL/2010/K_132_10.PDF, 22.06.2011 r. 
Respondenci mniejsze znaczenie przypisują wyborom prezydenckim i parlamentarnym. Jedyną zbieżność między znaczeniem a frekwencją odnotowano w wypadku wyborów do Parlamentu Europejskiego: respondenci najniżej cenią takie głosowanie (rys. 2).

Rysunek 2. Znaczenie wyborów dla Polaków.

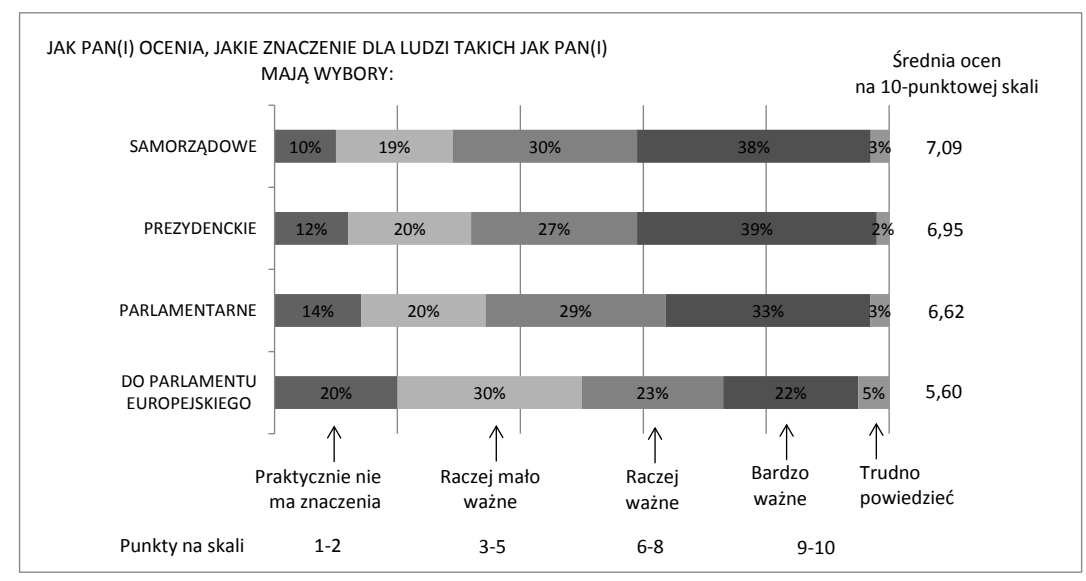

Źródło: R. Boguszewski, Wybory samorzadowe - znaczenie, zainteresowanie oraz deklaracje udziału $w$ glosowaniu. Komunikat z badań, CBOS, Warszawa 2010, http://www.cbos.pl/SPISKOM.POL/2010/K_132_10.PDF, 22.06.2011 r.

Potwierdzeniem tej zbieżności są wyniki frekwencji w wyborach do Parlamentu Europejskiego: w 2004 r. zagłosowało 20,87\% uprawnionych $^{18}$ (były to wówczas pierwsze $\mathrm{w}$ Polsce wybory do PE), zaś w 2009 r. - 24,53\% (rys. 3). Według Zdzisława Krasnodębskiego problem tak niskiej frekwencji tkwi w świadomości, gdyż „dla ludzi Unia to abstrakcja. Nie wierzą, że wybory te mogą mieć jakikolwiek wpływ na naszą sytuację w UE”19.

Dane przedstawione na rysunku 2. i 3. obalają więc twierdzenie, że lokalny wyborca jest nieświadomy ważności wyborów samorządowych, na które wskazuje Z. Krasnodębski. Czy słuszne jest więc twierdzenie według, którego niska frekwencja wynika z „niskiej świadomości politycznej, więcej - z niedojrzałości politycznej i obywatel-

${ }^{18}$ Oznacza to, że w wyborach do PE wziął udział co piąty Polak. Dane za: http:// www.pe2004.pkw.gov.pl/, 03.07.2011 r.

19 P. Jarosińska, Podziały..., op. cit. 
skiej Polaków?”2o. Zważywszy na wyniki badań, można przypuszczać, że świadomość obywateli tylko w nieznacznym stopniu determinuje decyzje wyborców. Tym samym jest to czynnik niewystarczający. Analizując niskie uczestnictwo wyborcze Polaków trzeba szerzej spojrzeć na ten problem, uwzględniając inne, oprócz świadomości politycznej, zmienne.

Rysunek 3. Frekwencja wyborcza w Polsce w wyborach do Parlamentu Europejskiego

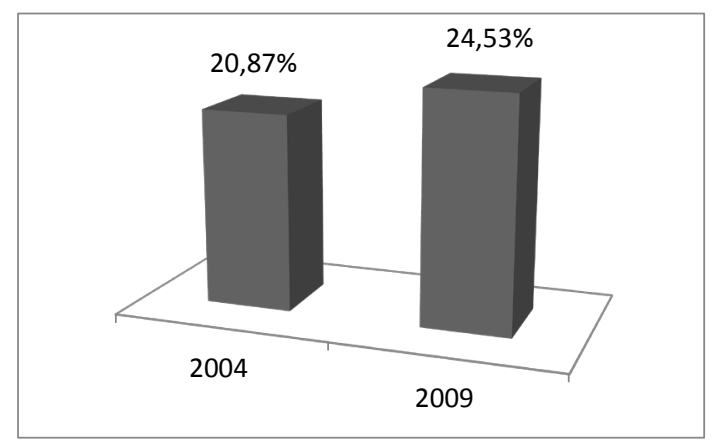

Źródło: Opracowanie własne na podstawie: PKW, Frekwencja w glosowaniu do Parlamentu Europejskiego, http://pe2009.pkw.gov.pl/PUE/PL/WYN/F/index. htm, 03.07.2011 r.; PKW, Wyniki wyborów, http://www.pe2004. pkw.gov.pl/, 3.07.2011 r.

\section{Przyczyny zobojętniania wyborców w Polsce}

NIE DO KOŃCA SŁUSZNYM JEST TWIERDZENIE jakoby polska świadomość polityczna była niska. Gdyby rzeczywiście tak było, obywatele wrzucaliby kartki do urn automatycznie, wyłącznie z poczucia obowiązku ${ }^{21}$. Tak się jednak nie dzieje. O decyzji wzięcia udziału w głosowaniu wyborcy decydują nad wyraz świadomie, bo na podstawie stosunku do polityki,

\footnotetext{
${ }^{20}$ Ibidem.

${ }^{21}$ Na pozytywny aspekt bierności politycznej zwraca uwagę S. M. Lipset: „dla dobrego funkcjonowania demokracji wskazany jest dość wysoki poziom wyborczej bierności obywatelskiej. Dzieje się tak dlatego, że brak zainteresowania polityką wiąże się na ogół ze słabą znajomością reguł i argumentów politycznych, brakiem rozeznania w stanowiskach partii i ich głównych aktorach oraz ze słabym różnicowaniem rozmaitych stanowisk politycznych. Im więcej osób „niedoinformowanych” bierze udział w wyborach, tym bardziej <<amatorskie>> kryteria demokracji”. Zatem, aby system był w miarę stabilny, powinna istnieć względna absencja wyborcza. Myśl S. M. Lipseta jest o tyle słuszna, że zwraca uwagę na istnienie osób niedoinformowanych, których udział w wyborach mógłby doprowadzić do rozregulowania systemu. Por.: K. Skarżyńska, Człowiek a polityka. Zarys psychologii politycznej, Warszawa 2005, s. 152.
} 
swoich doświadczeń, czy wiedzy. Niektórzy obywatele nie uczestniczą w wyborach, gdyż nie ufają politykom, a tym samym są przekonani o bezsensowności głosowania. Inni zaś rezygnują, gdyż nie dostrzegają alternatywnego kandydata lub partii politycznej. Czasem ludzie wolą pozostać w domu, gdyż nie wierzą politykom w ogóle, a scena polityczna jest dla nich miejscem nieistniejącej szansy. Tylko niektórzy ostatecznie decydują się wybrać tzw. „mniejsze zło” i zagłosować przeciwko jakiejś opcji. Stąd argument o niskiej świadomości obywateli zdaje się być odwróceniem uwagi od poważniejszego problemu, jakim jest wspomniany brak alternatywy, czy postępowania polityków, wzmacniające nieufność do nich wśród wyborców ${ }^{22}$. Dodatkowo, czynnikiem potęgującym może być kultura polityczna polityków, której niski poziom można dostrzec podczas debaty publicznej w Polsce. Przejawem jest język dyskursu, w którym dominują oskarżenia, inwektywy, insynuacje. W Polsce dotyczy to zwłaszcza dwóch ugrupowań: Platformy Obywatelskiej oraz Prawa i Sprawiedliwości. Napięte stosunki między politykami oraz zwolennikami tych dwóch partii od 2007 r. ${ }^{23}$ silnie wpływały lub wpływają na postawy wyborców, którzy albo głosowali negatywnie (przeciwko danej opcji) albo rezygnowali z udziału w wyborach, nie znajdując alternatywy lub odczuwając rozgoryczenie z powodu ostatnio dokonanego wyboru ${ }^{24}$.

${ }^{22}$ Por. B. Badora, Czy trzeba chodzić na wybory? Przyczyny absencji wyborczej. Komunikat z badań, CBOS, Warszawa 2011. Wśród wskazań respondentów na temat przyczyn własnej absencji wyborczej najczęściej podawano, że decydujący jest brak wiedzy na temat kandydatów, programów (19\%) oraz brak zainteresowania polityką i wyborami (17\%). Poszczególne powody podawane są z różną częstotliwością, w zależności od tego, czy ankietowani są zdecydowani, aby nie głosować, czy też jeszcze się wahają. Osoby niezdecydowane jako przyczynę niegłosowania najczęściej podawały niewiedzę oraz poczucie braku kompetencji wyborczych (28\%). Ci, którzy nie zamierzali głosować, najczęściej przyznają, że nie interesują się polityką i wyborami (21\%), a także częściej od niezdecydowanych stwierdzali, że są zniechęceni do polityków i rozczarowani samym mechanizmem wyborczym. Jednocześnie obie te grupy równie często mówią o braku odpowiednich partii i kandydatów (14\%), co w porównaniu z 2004 r. nie uległo zmianie. Natomiast niechęć czy brak zaufania do polityków jako powód absencji był rzadziej wskazywany, aniżeli w 2004 r. Na podstawie wyników badań, można obalić stwierdzenie o braku świadomości politycznej wyborców. Taka świadomość istnieje, a dowodem na to jest podejmowanie decyzji o głosowaniu na podstawie przesłanek, które w gruncie rzeczy wydają się być racjonalne. Zwłaszcza, jeżeli pod uwagę weźmie się teorię S. Lipseta o pozytywnym skutku niegłosowania: czasem lepiej, gdy nie głosują ci, którzy nie mają wiedzy. Można bowiem przypuszczać, że gdyby zagłosowali, wynik mógłby być negatywnie zaskakujący. Zob. K. Skarżyńska, Człowiek..., op. cit., s. 152.

${ }^{23}$ Por. U. Panicz, Kreowanie dyskursu publicznego w Polsce - rola mediów krytycznych wobec Prawa i Sprawiedliwości, „Refleksje” 2011, nr 3, s. 141-156.

24 „Słyszę desperackie konkluzje: „Nie ma w czym wybierać”, a brzydko mówiąc, 
Poziom zaufania do polityków determinuje decyzje o uczestnictwie w wyborach. Dodatkowo wsparcie dla takiej decyzji podtrzymują inne czynniki, które z racji pełnienia funkcji wzmagającej podejmowane decyzje wyborczych, można nazwać wzmocnieniami. Owe wzmocnienia działają w obu kierunkach, zachęcając lub zniechęcając do udziału w akcie wyborczym, stąd można nadać im charakter aktywny lub pasywny. Te o charakterze pasywnym są odpowiedzialne za bierność wyborczą. Ogólnie rzecz biorąc są to te wszystkie utrudnienia, które mogą wpłynąc demobilizująco na wyborcę, czyli są to przede wszystkim koszty, jakie musi ponieść wyborca. Do wymiernych kosztów można zaliczyć: konieczność rejestracji ${ }^{25}$, znalezienie właściwego lokalu, połączone z czasem i wysiłkiem, które wymusza dotarcie do takiego miejsca w dniu wyborów ${ }^{26}$. Również zasięgnięcie informacji o kandydatach, czy partiach może sprawiać trudności: „nie każdy jest w stanie dowiedzieć się o nich choćby tyle, żeby ich odróżnić. Niektórzy ludzie mogą uważać bilans tych kosztów za nazbyt pokaźny, żeby się nim obciążać” ${ }^{27}$. Do czynników ograniczających udział w wyborach można zaliczyć również stan pogody oraz stan fizyczny i psychiczny samego wyborcy. Deszczowa pogoda lub upalny dzień może nie sprzyjać mobilizacji wyborcy ${ }^{28}$. Również złe samopoczucie może zdecydować o głosowaniu lub jego braku. Do wzmocnień o skutku pasywnym można

że to wybór „między dżumą a cholerą.”. Ktoś inny, sprzed czterech lat wyborca Platformy Obywatelskiej, jest rozgoryczony na nią, podobno nie pójdzie głosować. Ten i ów kręci głową, jęczy i wzdycha, nadymając banię przygnębienia. Takie opinie przekazuje się paru milionom widzów...”. Zob. S. Bratkowski, Wybór cywilizacji, „Studio opinii”, http://studioopinii.pl/artykul/1329-stefan-bratkowski-wybor-cywilizacji, 14.11.2011 r.

${ }^{25} \mathrm{~W}$ Polsce system rejestracji wyborcy jest automatyczny, więc nie wymaga jakiejkolwiek własnej inicjatywy wyborców. $Z$ tego względu jest to czynnik o charakterze aktywnym, ułatwia uczestnictwo wyborcze. W tym miejscu należy rozróżnić konieczność rejestracji od charakteru rejestracji, która jest pojęciem ogólnym. Dopiero uszczegółowienie daje podstawy do tego, by czynnik sklasyfikować jako wzmocnienie o skutku pasywnym, bądź wzmocnienie o skutku aktywnym.

${ }^{26}$ Zob. więcej: Ruy A. Teixeira, Znikający wyborca w Ameryce, [w:] Władza i społeczeństwo. Antologia tekstów z zakresu socjologii polityki, t. 2, red. J. Szczupaczyński, Warszawa 1998, s. 277-283.

${ }^{27}$ Ibidem.

${ }^{28}$ José Saramago w swej powieści Miasto białych kart pośrednio zwrócił uwagę na pogodę jako czynnik wpływający na frekwencję wyborczą. W opisywanym dniu wyborów przez połowę dnia padał deszcz. W ciągu tego czasu, do urn udało się niewiele osób. Dopiero kilka godzin po poprawie pogody, do urn pofatygowało się nieco więcej wyborców. „Zła pogoda na wybory, poskarżył się przewodniczący komisji wyborczej numer czternaście, energicznie złożywszy parasol i ściągnąwszy płaszcz, który na niewiele mu się zdał (...)”. Zob.: J. Saramago, Miasto białych kart, Poznań 2009, s. 9-26. 
zaliczyć również korzyści z głosowania. Wyborca, biorący udział w głosowaniu, musi otrzymywać realną korzyść z aktu wyborczego. Jednak teoretycy wykazują, że korzyść z głosowania „W ogromnej większości wypadków musi być (...) niewielka, ponieważ minimalne jest prawdopodobieństwo, iż pojedynczy głos wpłynie na ostateczny rezultat”. Tym samym wartość oczekiwana nie zawsze jest wartością urzeczywistnianą. Co więcej, bilans kosztów i korzyści stanowi paradoks demokracji, dlatego że „koszty nie redukują się do zera, a za to korzyści mogą być zerowe". Takie wzmocnienie ma skutek pasywny jako, że częstokroć wyborca nie angażuje się w akt, do którego musi „dopłacać”"2.

Koszty ponoszone przez wyborców mogą zostać zredukowane przez wzmocnienia o skutku aktywnym. Ich celem jest pobudzanie aktywności wyborczej poprzez minimalizację kosztów oraz redukcję utrudnień, a także uświadamianie korzyści z głosowania. Takim sposobem jest chociażby ułatwienie dotarcia do lokalu w dniu wyborów. Niektóre gminy ${ }^{30}$ zapewniają specjalne autobusy, które zawożą wyborców do lokalu wyborczego. Ułatwieniem jest też organizowanie wyborów w dzień wolny od pracy. Najbardziej wskazane jest to, by nie odbywały się one w wakacje lub w czasie dłuższych weekendów, kiedy ludzie zwykle opuszczają miejsce swego zamieszkania. Kwestię korzyści z uczestnictwa w wyborach, o których była mowa wyżej, można rozwiązać poprzez uświadomienie wyborcy, że symboliczne lub instrumentalne korzyści ${ }^{31}$ wynikające z tego aktu są wystarczające, by zrekompensować poniesione koszty.

Zarówno wzmocnienia o charakterze aktywnym, jak i pasywnym mogą działać różnie w odmiennych warunkach. Przykładowo fakt, że władze gminy zorganizowały dojazd do lokalu wyborczego może być bardziej mobilizujący w mniejszych miejscowościach, gdzie kontrola społeczna jest większa, niż w większych, gdzie kontrola jest raczej rozproszona. Czasem może to oznaczać, że w mniejszych zbiorowościach frekwencja wyborcza powinna być większa, na co wskazuje się w mo-

${ }^{29}$ R. A. Teixeira, Znikajacy..., op. cit., s. 277.

3o Przykładem takiego postępowania jest cykliczna akcja organizowana m.in. przez Gminę Rymań w województwie zachodniopomorskim.

${ }^{31}$ Symboliczne korzyści, to głównie sam fakt manifestacji swego zaangażowania na rzecz określonej partii, grupy odniesienia, sprawy ogólnej, który możliwy jest poprzez udział w głosowaniu. Korzyści instrumentalne dotyczą głosowania jako aktu, mającego wpływ na politykę rządu, czy jego skład personalny. Wyborca podejmuje decyzje o zagłosowaniu, dlatego że interesują go jedynie same wybory. Zob. R. A. Teixeira, Znikający..., op. cit. 
delu słabnięcia społeczności ${ }^{32}$. Zakłada on, że w mniejszych miastach i wsiach, ze względu na ich rozmiar, istnieją społeczności, którymi można skutecznie zarządzać. Dodatkowo w takich małych społecznościach „obywatele dobrze wiedzą, z kim mają się kontaktować, aby dowiedzieć się istotnych dla nich rzeczy o polityce i politykach, mają więcej niż mieszkańcy wielkich miast nieformalnych kontaktów i spotkań, na których rozmawiają między innymi o polityce"33. W świetle powyższych rozważań, można sądzić, że wzmocnienia o skutku pasywnym, tj. np. trudność znalezienia informacji o kandydacie, w małych społecznościach nie występuje. Jest to jednak zbyt daleko idący wniosek, dlatego że model słabnięcia społeczności zdaje się zakładać pewien ideał, jakim jest istnienie choćby świadomego politycznie społeczeństwa, dyskutującego o sprawach politycznych ${ }^{34}$.

Wymieniając przyczyny zobojętniania wyborcy polskiego, obok już wspomnianych, warto zwrócić uwagę na stosunek Polaków do demokracji. Jest to wskaźnik, który również może wyjaśniać poziom polskiej frekwencji. Badania stosunku do demokracji wskazują na to, że Polacy negatywnie oceniają demokrację w Polsce. Jak widać w tabeli 1., liczba osób niezadowolonych w większości przypadków przeważa nad osobami zadowolonymi z funkcjonowania demokracji. Jedynie w 2007 roku odnotowano, że zadowoleni z działania demokracji byli nieco liczniejszą grupą, niż niezadowoleni. Zmiana w tym okresie okazała się jednak krótkotrwała, co potwierdzają kolejne pomiary. Ubiegłoroczne

${ }^{32}$ K. Skarżyńska, Człowiek..., op. cit., s. 206.

33 Takiemu modelowi przeciwstawia się tryb mobilizacyjny, w którym zwraca się uwagę na to, że wyższa frekwencja wyborcza występuje w większych miastach ze względu na łatwiejszy dostęp do informacji, częstsze kontaktowanie się z ludźmi dobrze poinformowanymi lub aktywnymi politycznie. Taka właściwość wynika z bardziej centralnych pozycji, zajmowanych w środowisku społeczno-politycznym. K. Skarżyńska, Cztowiek..., op. cit., s. 206.

${ }^{34}$ Stefan Nowak niejako potwierdził tezę, wedle której chociażby model słabnięcia społeczności zakłada pewien ideał. Według niego w Polsce istnieją jedynie dwa wymiary organizujące życie społeczne: poziom abstrakcyjnej wspólnoty narodowej oraz sfera prywatności zogniskowana wokół rodziny. Pomiędzy tymi biegunami jest pustka - socjologiczna próżnia. Oznacza to, że nie ma nic - ani spontanicznych zachowań społecznych, ani inicjatyw obywatelskich, ani licznych stowarzyszeń, ani silnych ruchów społecznych. Skoro nie dochodzi do takich zachowań, wówczas mówienie o wyższej frekwencji wyborczej w przypadku małych zbiorowości - przestrzeni pomiędzy wspólnotą narodową a sferą prywatną, jest bezzasadne. Co więcej, powodem próżni jest wyalienowanie, które zasadza się na przekonaniu, że nie ma się dostatecznego wpływu na sprawy. Obywatele ograniczają się do sfery prywatnej, przyjmując postawy obojętności wobec tego, co publiczne. Por. S. Nowak, System wartości społeczeństwa polskiego, „Studia Socjologiczne" $1979, \mathrm{nr} 4$. 
badania wskazują, że ponad dwie piąte Polaków (43\%) dobrze ocenia funkcjonowanie demokracji w Polsce, a dokładnie połowa (50\%) jest przeciwnego zdania. Tendencje utrzymujące się od 2008 do $2010 \mathrm{r}$. świadczą o niemal niezmiennych opiniach o demokracji. Co więcej, od 2007 r. różnica między osobami zadowolonymi i niezadowolonymi zmniejszyła się. Nadal niezmiennie przeważają opinie negatywne, co przy jednoczesnym wzroście frekwencji może być zaskoczeniem, zaś z drugiej strony może świadczyć o wyraźnej mobilizacji osób niezadowolonych ${ }^{35}$.

Tabela 1. Stosunek do funkcjonowania demokracji w Polsce.

\begin{tabular}{|c|c|c|c|c|c|c|c|c|c|c|c|c|c|c|c|c|c|c|c|c|c|c|c|c|c|c|}
\hline \multirow{4}{*}{$\begin{array}{l}\text { Stosunek } \\
\text { do funkc- } \\
\text { jonowania } \\
\text { demokracji } \\
\text { w naszym kraju }\end{array}$} & \multicolumn{26}{|c|}{ Wskazania respondentów według terminów badań } \\
\hline & $\mathrm{XI}$ & $\mathrm{V}$ & $\mathrm{X}$ & $\mathrm{XI}$ & $\mathrm{X}$ & $\mathrm{V}$ & III & $\mathrm{XII}$ & IV & $\mathrm{x}$ & $\mathrm{XI}$ & III & III & VII & $\mathrm{V}$ & $\mathrm{XI}$ & IX & $\mathrm{XI}$ & II & $\mathrm{XI}$ & IV & $\mathrm{V}$ & $\mathrm{XI}$ & VII & $\mathrm{I}$ & III \\
\hline & “93 & '95 & '95 & '96 & '97 97 & 98 & 99 & |'99] & 'oo & 'oo & '01 & '02 & '03 & '03 & '04 & '04 & '05 & 05 & '06 & '06 & '07 & ‘07 & '07| & '08 & '09 & 10 \\
\hline & \multicolumn{26}{|c|}{ w procentach } \\
\hline Zadowoleni & 36 & 24 & 30 & 44 & 40 & 41 & 28 & 35 & 27 & 37 & 34 & 24 & 22 & 20 & 21 & 26 & 32 & 34 & 40 & 30 & 31 & 32 & 46 & 43 & 42 & 43 \\
\hline Niezadowoleni & 52 & 67 & 58 & 47 & 50 & 46 & 62 & 56 & 64 & 51 & 53 & 64 & 67 & 71 & 68 & 63 & 58 & 56 & 46 & 58 & 59 & 54 & 42 & 47 & 49 & 50 \\
\hline $\begin{array}{l}\text { Trudno } \\
\text { powiedzieć }\end{array}$ & 12 & 9 & 12 & 9 & 10 & 13 & 10 & 9 & 9 & 12 & 14 & 12 & 11 & 9 & 11 & 12 & 10 & 10 & 14 & 12 & 10 & 14 & 12 & 10 & 9 & 7 \\
\hline
\end{tabular}

Źródło: M. Feliksiak, Postawy wobec demokracji, jej rozumienie i oceny. Komunikat z badań, CBOS, Warszawa 2010, http://www.cbos.pl/SPISKOM.POL/2010/ K_060_10.PDF, 22.06.2011 r.

Stosunek do funkcjonowania demokracji w Polsce jest wartością dynamiczną. Zmieniał się pod wpływem istotnych wydarzeń społeczno-politycznych. I tak najwyższy wskaźnik niezadowolenia odnotowano w lipcu 2003 r. (71\%), co mogło mieć związek z ujawnioną we wrześniu 2002 r. aferą Rywina. Wysoki poziom utrzymywał się jeszcze w 2004 r. (w maju - 68\% i wrześniu - 63\%), co wiązało się z ww. skandalem korupcyjnym. Najniższy poziom niezadowolenia zaobserwowano w listopadzie 2007 r. (42\%), co było związane z wyborami parlamentarnymi oraz zwycięstwem Platformy Obywatelskiej. Wysokie niezadowolenie przed listopadem $2007 \mathrm{r} .{ }^{36}$ można wiązać z kolei z niewyłonieniem większościowego rządu po wyborach w październi-

${ }^{35} \mathrm{O}$ uczestnictwie wyborczym decyduje także chęć zmiany sytuacji, co tłumaczy występowanie jednocześnie: wysokiej frekwencji oraz wysokiego poziomu niezadowolenia z funkcjonowania demokracji.

${ }^{36}$ Wyższe, niż w XI 2007 r. niezadowolenie odnotowano po wyborach w X 2005 r. w dwóch okresach: w XI 2005 r. (56\%) oraz II 2006 r. (46\%). 
ku 2005 r., powstałym wówczas gabinetem mniejszościowym, koalicją PiS-Samoobrona-LPR oraz zajęciem stanowisk wicepremierów przez kontrowersyjnych polityków ${ }^{37}$. Wszystkie te problemy wywarły duży wpływ na życie społeczno-polityczne w Polsce, co też było widoczne w stosunku Polaków do funkcjonowania demokracji.

Wymienione czynniki, czyli wzmocnienia o charakterze pasywnym i aktywnym oraz stosunek do demokracji, zaufanie do polityków to tylko niektóre z czynników wpływających znacząco na poziom frekwencji w Polsce $^{38}$. Dodatkowo można je sklasyfikować, dzieląc na trzy grupy: tradycje kulturowe, historyczne i społeczne oraz cechy sytuacji wyborczej, a także cechy jednostek: społeczno-demograficzne i psychologiczne ${ }^{39}$.

\section{Podsumowanie}

WyBory SĄ PROCEDURALNYM ELEMENTEM DEMOKRACJI: pozwalają legitymizować władzę, obrazują stosunek wyborców do polityków, partii, czy wreszcie całego systemu. Są podstawowym rodzajem uczestnictwa politycznego. Taki udział wiąże się z zasadami demokratycznymi: równością, wolnością, legitymizacją władzy. O wadze wyborów świadczą zabiegi, mające na celu zwiększenie frekwencji wyborczej.

W Polsce, frekwencja wyborcza utrzymuje się na średnim poziomie: od 2005 r. w wyborach parlamentarnych oraz prezydenckich oscyluje wokół 50\% (wyjątek: wybory parlamentarne z 2005 r. - 40,57\%). Gorsze wyniki są obserwowane na poziomie lokalnym oraz w wyborach do Parlamentu Europejskiego. Za główną przyczynę wskazuje się tu: brak świadomości politycznej oraz niewykształcone społeczeństwo obywatelskie w przypadku wyborów samorządowych, a także niezrozumienie mechanizmów funkcjonowania Unii Europejskiej w przypadku wyborów do Parlamentu Europejskiego. Jednak badania prowadzone przez Centrum Badania Opinii Społecznej wskazują na inne powody absencji wyborczej, wśród których ważne miejsce zajmuje brak zainteresowania polityką oraz nieistnienie alternatywnego kandydata lub partii politycznej.

${ }^{37}$ Zob. więcej: http://portalwiedzy.onet.pl/10072,,,,polska,haslo.html\#424, 14.11.2011 r.

${ }^{38}$ Poza wymienionymi można wskazać również na czynniki społeczne (np. ilość wolnego czasu, kontakty i komunikowanie się). Zob. więcej: S. Lipset, Homo..., op. cit., s. 190-234. Por. K. Skarżyńska, Człowiek..., op. cit., s. 204-220.

${ }^{39}$ K. Skarżyńska, Człowiek..., op. cit., s. 204. 
Znaczenie frekwencji wyborczej w Polsce potwierdza jednogłośne uchwalenie w grudniu 2010 r. nowego Kodeksu wyborczego ${ }^{40}$. Zmiany, jakie wprowadziła ustawa, to m.in. dwudniowe głosowanie ${ }^{41}$, ułatwienia dla niewidzących (karty z pismem Braila) oraz możliwość głosowania przez pełnomocnika. Mikołaj Cześnik podkreśla, że zmiana instytucjonalna (czyli jakakolwiek zmiana prawa wyborczego) może wpłynąć na zwiększenie frekwencji wyborczej: „efekt nowości może podnieść zainteresowanie obywateli procedurą wyborczą, choć oczywiście nie musi tak być"42.

Wydaje się, że zwiększenie frekwencji jest sprawą skomplikowaną bowiem wysokiego poziomu uczestnictwa w Polsce nie da się osiągnąć ad hoc. Problem tkwi nie tylko $\mathrm{w}$ rozwiązaniach instytucjonalnych, ale także, a może przede wszystkim, w mentalności wyborców oraz kulturze politycznej samych polityków. Częstokroć wyborca nie chce brać udziału w polityce, gdyż nie ufa politykom, nie widząc korzyści ze swego zaangażowania. Można zatem sądzić, że tak długo, jak kultura polityczna w Polsce nie osiągnie wyższego poziomu, tak długo niektórzy obywatele będą stronić od udziału w głosowaniu. Co więcej, utrzymująca się niska kultura polityków może dodatkowo powodować odpływ wyborców, a tym samym zwiększać poziom absencji wyborczej, prowadząc nawet do „cichej” delegitymizacji systemu.

\section{SUMMARY}

LAST LOCAL ELECTION SHOWED that the voter turnout in Poland is low and not everybody wants to participate in election. This article tries to find the causes of this situation in Poland while underlining the importance of turnout. What is more, the aim of this article is to show that

${ }^{40}$ D. Zaczek, Nowy Kodeks Wyborczy uchwalony, „Polskie Radio”, http://www2. polskieradio.pl/radioparlament/rozmowadnia/artykul192692_nowy_kodeks_wyborczy_uchwalony.html, 03.07.2011 r.

${ }^{41}$ Zamiarem tej zmiany było zwiększenie frekwencji wyborczej. Zanim jednak wypróbowano efektywność działania nowego przepisu, do Trybunału Konstytucyjnego Grupa posłów na Sejm zgłosiła wniosek o niezgodność zapisów Kodeksu wyborczego z Konstytucją RP. Trybunał orzekł m.in., że „konstytucja przesądza, iż wybory do Sejmu i Senatu oraz na urząd Prezydenta RP muszą być przeprowadzone w ciągu jednego dnia. Wyroki dotyczyły także m.in. głosowania korespondencyjnego, okręgów jednomandatowych oraz głosowanie przez pełnomocnika. Zob. więcej: http://www.trybunal.gov.pl/ Rozprawy/2011/k_09_11.htm, 14.11.2011 r.

${ }^{42}$ M. Cześnik, Partycypacja..., op. cit., s. 93. 
increasing the number of people who vote is quite difficult. It is caused by so many various reasons.

\section{NOTA O AUTORCE}

Urszula Panicz [panicz.ula@wp.pl] - studentka II roku studiów II stopnia na Wydziale Nauk Politycznych i Dziennikarstwa Uniwersytetu im. Adama Mickiewicza w Poznaniu. Przewodnicząca Koła Naukowego Samorządu Terytorialnego, szef działu Aktualności w wydziałowej gazecie - BUC. Zainteresowania: polityka, media, publicystyka. 
